Pamiętnik Literacki 2019, 4, s. 129-147

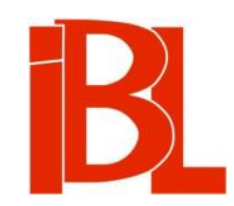

\title{
O nieznanym rosyjskim rękopisie Aleksandra Wata
}

Adam Dziadek, Piotr Fast 


\section{O NIEZNANYM ROSYJSKIM REZKOPISIE ALEKSANDRA WATA}

Tekst, o którym mowa w tytule, zalegał do tej chwili w teczkach archiwalnych zbiorów zawierających materiały dotyczące poety, opatrzonych nazwą Aleksander Wat Papers i oznaczonych sygnatura GEN MSS 705, przechowywanych w Beinecke Library w Yale University. Powstała w jezzyku rosyjskim Priczta o worobje, mużykie i wotkie (Przypowieść o wróblu, chłopie i wilku), zgodnie $\mathrm{z}$ informacją dołączoną do manuskryptu przez żonę Wata, Olę, to: „Tekst żartobliwy, napisany na prośbę N. Nabokova do jego muzyki r. 1963 (?) przed wyjazdem do Berkeley".

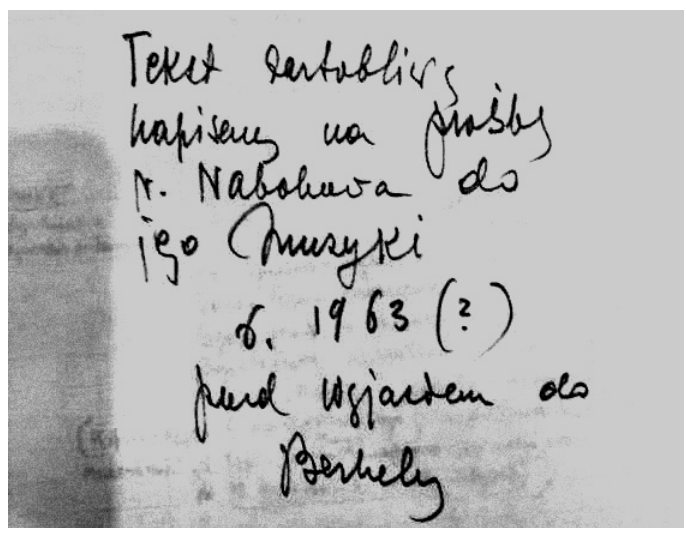

Utwór ten znajduje się pośród innych rękopisów w teczce posiadającej sygnaturę B22 F467. Rzeczywiście, musiał powstać przed wyjazdem Watów do Berkeley, a dokładną datę wskazuje Vincent Giroud, monografista Nicolasa Nabokova: „September 7-8, 1962" .

Nicolas Nabokov (a właściwie: Nikołaj Dmitrijewicz Nabokow), kuzyn wybitnego pisarza Vladimira Nabokova, urodził się w Lubczy w rodzinie szlacheckiej w roku 1903, a zmarł w 1978 roku w Nowym Jorku. Jak wielu z jego pokolenia, do-

1 V. Gi r o u d, Nicolas Nabokov: A Life in Freedom and Music. Oxford 2015, s. 521. Autor ten wskazuje tu maszynopis w języku rosyjskim. Jako kurator zbiorów Beinecke Library w latach 1987-2004 Giroud, który przejmował archiwum Aleksandra Wata od Oli Watowej w roku 1989, znał zapewne także rękopis przedstawiony w niniejszej publikacji. 
świadczył ucieczki przed rewolucją bolszewicką i emigracji, wpierw przebywał krótko na Krymie i w Niemczech, potem osiedlił się w Paryżu i ostatecznie wyjechał do Stanów Zjednoczonych. Katalog jego kompozycji obejmuje dzieła operowe (Rasputin's End oraz Love's Labour's Lost), baletowe (np. Union Pacific, La Vie de Polichinelle), symfoniczne i kameralne, jak też inspirowane pisarstwem Borisa Pasternaka, Anny Achmatowej, Aleksandra Puszkina, Emily Dickinson. Był dobrze znaną i ważną postacią w świecie kultury emigracyjnej, przyjaźnił się z takimi twórcami, jak Isaiah Berlin czy Igor Strawiński, a także Jarosław Iwaszkiewicz². Angażował się $\mathrm{w}$ wiele przedsięwzięć związanych $\mathrm{z}$ działalnością polityczną i kulturalną emigracji, aktywnie uczestniczył m.in. w pracach Kongresu Wolności Kultury (Congress for Cultural Freedom), w którym przez pewien czas kierował sekretariatem $^{3}$. Znajomość z Aleksandrem Watem zawarł najprawdopodobniej za pośrednictwem Konstantego Aleksandra Jeleńskiego lub Józefa Czapskiego ${ }^{4}$, związanych również z Kongresem.

Przypowieść Wata miała być librettem do muzyki Nabokova, która jednak nigdy nie powstała. Jak wiele dzieł kompozytora, pozostała w zamyśle twórczym, wiemy jedynie, że ta „kantata kameralna”, jak ją nazywał Nabokov, była jednym $\mathrm{z}$ nigdy nie wykonanych projektów nakreślonych przez niego w początkach lat sześćdziesiątych. W korespondencji Nabokova $\mathrm{z}$ chorwackim kompozytorem Milko Kelemenem znajduje się szerszy opis tej „kantaty”, której skład wokalno-instrumentalny wyglądać miał tak: „set for a speaker, a small singing choir, two magnetophones with loudspeakers, a group of four drums, two basses, a cello, a violin, a trombone, a xylophone and vibraphone [narrator, niewielki chór, dwa magnetofony z głośnikami, cztery bębny, dwa basy, wiolonczela, skrzypce, puzon, ksylofon i wibrafon]" 5 .

W zbiorze dokumentów składających się na Aleksander Wat Papers znajduje się tylko jeden ślad znajomości Wata $z$ Nicolasem Nabokovem - jest to list adresowany przez Nabokova do poety, a zawierający m.in. komentarze na temat Przypowieści. W liście znajduje się sporo odwołań i krytycznych uwag do napisanego przez Wata libretta - to sprawa, do której wypadnie jeszcze nawiązać.

Przypowieść nie do końca jest tekstem żartobliwym, jak chciałaby tego Ola Watowa, ale miejscami ponurym i gorzkim, przesyconym - podobnie jak wiele utworów Wata - nie tyle napiętą do granic ironią, ile wręcz sarkazmem. Można by je określić nazwa gatunkową „sarkazmy”, jaka posłużył się niegdyś inny rosyjski kompozytor, Siergiej Prokofjew, nazywając w ten sposób cykl swoich dzieł.

W tym rosyjskim tekście Wata da się dostrzec dużo cech charakterystycznych dla jego twórczości poetyckiej. Przypomina jego wiersze powstałe jeszcze w okresie

2 Zob. J. Iw a szki ew i c z, Książka moich wspomnień. Warszawa 1975, s. 238, 260.

3 Niewielką wzmiankę na ten temat można znaleźć w: A. Fra na sze k, Miłosz. Biografia. Kraków 2012, s. 493-494. Zob. też A. S. Kow al c zy k, Od Bukaresztu do Laffitów. Jerzego Giedroycia rzeczpospolita epistolarna. Sejny 2006, s. 221. O współpracy Nabokova z Kongresem Wolności Kultury szerzej pisze Gi r o u d w cytowanej tu monografii; zob. zwłaszcza rozdz. 17 i 18.

4 Zob. Gi r o u d, op. cit., s. 336. Taką możliwość zawarcia znajomości potwierdza również syn poety Andrzej Wat.

5 Cyt. jw. 
futurystycznym czy też nigdy przezeń nie opublikowane fraszki ${ }^{6}$ oraz krótkie formy prozatorskie zbliżone swoim kształtem do powiastki filozoficznej. Także w zakresie poetyki wyczuwa się wyraźnie cechy charakterystyczne dla pisania Wata. Uderzające są zwłaszcza zabiegi fonetyczne, bogata i złożona sfera brzmień utworu. Zarówno w polskich wierszach Wata, jak i w tym niewielkim tekście rosyjskim mamy do czynienia $z$ bardzo silną fokalizacją brzmieniowa, $z$ całymi seriami ech konsonantycznych $-z$ praktyką pisania anagramatycznego, $z$ którego wyłania się wtórny, dodany do pierwotnego słowa sposób znaczenia, niezwykle bogata warstwa sensów opartych na signifiants, kształtująca dodatkowo rytm tekstu oraz eksponująca niepowtarzalną sygnaturę podmiotu mówiącego.

Analizując tekst Wata, czytelnik może być rozdarty tysiącem sprzecznych uczuć. Wat wykorzystuje bowiem w sposób, by tak rzec, ambiwalentny pewne konwencje genologiczne, utrwalone w rosyjskiej pamięci gatunkowej. Zawarte w tytule określnie „priczta” nieco odmiennie znaczy w językowym poczuciu Rosjanina niż nasza „przypowieść”. W tradycji rosyjskiej to bowiem wpierw „mały dydaktyczno-alegoryczny gatunek, zawierający moralną lub religijną naukę ("mądrość"). Bliska [jest] baśni [...]"7 . Autorzy stosownego hasła w rosyjskim internetowym słowniku terminów literackich dopiero na końcu dodają w nawiasie, że teksty należące do tego gatunku pojawiają się m.in. w Ewangelii. Jak wiadomo - i co łatwo wyczytać w artykule hasłowym napisanym przez Janusza Sławińskiego w Słowniku terminów literackich - w naszej tradycji jest to jednak forma gatunkowa o większej wadze, raczej unikająca skojarzeń $z$ tradycją folklorystyczną i błahym pseudomoralizatorstwem. Może dzieje się tak dlatego, że w rosyjskich konwencjach gatunkowych nie utrwaliła sie jako oddzielna forma genologiczna konstrukcja podobna do naszej powiastki (filozoficznej). Rosyjskie słowo „priczta” obejmuje więc obie te odmiany gatunkowe. Stwarza to dość specyficzną sytuację, w której polski autor, świadomy rodzimych konotacji gatunkowych, używa w tekście rosyjskim odniesienia do przypowieści niejako w cudzysłowie, bo przecież traktuje ją z przymrużeniem oka. Ów dystans do opowiadanej historii przejawia się też w utworze Wata poprzez bezpośrednie nawiązanie do kilku cech literatury folklorystycznej - i to dwojakiego co najmniej autoramentu. $Z$ jednej strony, autor bogato inkrustuje repliki jednego z bohaterów, Chłopa, naleciałościami gwarowymi (raczej „pseudogwarowymi”), $\mathrm{Z}$ drugiej natomiast - prowadzi opowiadaną historię w taki sposób, że jej puenta mieści się w domenie common sense. Albo wręcz - żartu z powagi konwencji gatunkowej ${ }^{8}$. Taka gra $\mathrm{z}$ normami literatury moralizatorskiej przypomina Bachtinowską karnawalizację i sytuowałaby tekst Wata raczej w domenie literatury prześmiewczej. Byłoby tak, gdyby nie ostateczna puenta libretta polskiego poety. Akcent zostaje tu bowiem przeniesiony z żartobliwego pseudopouczenia na realne zagrożenia,

6 Zob. A. Wat, Notatniki. Transkrypcja, oprac. A. Dziadek, J. Zi eliński. Warszawa 2015, s. 17-146.

7 Na stronie: http://slovar.lib.ru/dictionary/pritcha.htm (data dostępu: 9 X 2019).

8 Nawiasem dodam, iż w latach pięćdziesiątych XX wieku krążyła w Polsce opowieść-anegdota o niezwykle podobnej zawartości, spuentowanej - pamiętam to świetnie - stwierdzeniem, że nie zawsze jest źle, gdy ktoś kogoś osra, i nie zawsze jest dobrze, gdy ktoś kogoś z gówna wygrzebie. 
jakie czyhają na wróbelka (maleńkiego/zwykłego człowieka - to oczywista alegoria) w rzeczywistości Rosji. Wat pisał swój tekst na emigracji i miał on być librettem do utworu komponowanego przez emigracyjnego muzyka, ale polski autor zawarł w nim wiele aluzji do sowieckiej rzeczywistości.

\author{
Słuchaj, mój przyjacielu, ludowej mądrości: \\ Gdy siedzisz w gównie - \\ MILCZ.
}

Te trzy ostatnie wersy utworu odwracaja sens zdroworozsądkowej „mądrości” zawartej w anegdotycznej opowieści. Odsyłaja do zagrożeń nad wyraz realnych w czasach, gdy Wat przebywał w Rosji, które nic nie straciły na aktualności na początku lat sześćdziesiątych, kiedy Wat libretto napisał.

Nicolas Nabokov z niezwykłym wyczuciem dostrzegł słabsze strony tekstu Wata. We wspomnianym liście z 2 września 1963 przekazuje kilka komentarzy do otrzymanego rękopisu. Konstatuje: „Zbyt wiele jest na tych pięciu stroniczkach rzeczy, o których w liście nie da się na- i o-pisać”, by mimo to przejść do uwag szczegółowych. Przede wszystkim wyraża zaniepokojenie: „Nieco się obawiam prostackiej ludowej stylizacji (i na dodatek sowieckości, której nie znam i znać nie chcę. Może

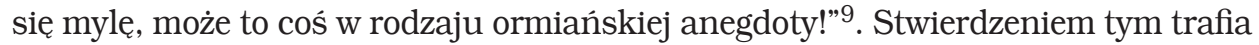
w samo sedno nie dość chyba starannie ukrytej intencji autora tekstu. Wat, wykorzystując formułę uniwersalizującej powiastki, prowadzi ją jednak ku aktualizującej puencie o wydźwięku politycznym, obniżając równocześnie ton utworu. Czyni to najpierw poprzez tę przeszkadzająca kompozytorowi ludową stylizację, a potem poprzez zastosowanie ludycznej konwencji opowiadanego podczas biesiady kawału. Jednak sformułowanie „ormiańska anegdota” to wyraźny sygnał, że Rosjanin widział w tym tekście pospolitość i trywialność.

Czytajmy dalej list Nabokova:

Druga uwaga, którą chciałbym uczynić, dotyczy niejasności na stronie drugiej (zapomniałem może, że bouse-de-vache [fr. dosłownie: krowie łajno] nazywa się po rosyjsku "guziennica..." Czy to nie za bardzo archaiczne i niezrozumiałe?). Wydaje mi się, że wszystko, co się dzieje w tej przypowiastce, powinno być absolutnie jasne.

Jak widać, Nabokovowi przeszkadza nadmierna stylizacja gwarowa, w szczególności użycie słowa, które nie będzie w sposób oczywisty zrozumiałe nawet dla Rosjanina. Oczekuje od libretta klarowności i jednoznaczności. Myślę, że grzeczność nie pozwoliła mu też oprotestować nadmiaru zawartych w tekście Wata wulgaryzmów i wulgarnych konotacji, bardzo obniżających ton całości - rzecz cała bowiem wręcz tapla się wraz z wróbelkiem w gównie. Nie wiemy tego, ale Nabokov raczej nie zmierzał w kierunku buffo.

I jeszcze dwa komentarze kompozytora. Łagodząc nieco poprzednią uwagę, Nabokov konstatuje, że na zrozumienie tekstu w dużym stopniu wpływa metoda jego czytania (,wiele zależy tutaj od prawidłowego przeczytania [...]") - kompozytor odnosi się w ten sposób do pewnych oznaczeń zawartych w rękopisie, takich jak

9 W ostatnich zdaniach listu $\mathrm{N}$ a b o k ov jeszcze raz, jak gdyby deprecjonując nieco jego wydźwięk, odwołuje się do tej kategorii. Pisze: „Proszę wybaczyć ten ormiański list”. 
pojedyncze i podwójne ukośniki, myślniki nie związane z normą interpunkcyjna, dzielenie słów łącznikami, co najpewniej w intencji Wata miało oddawać właśnie chwyty intonacyjne i akcenty logiczne. Nabokov postrzega je jednak jako uchybienia, podobnie jak stosowane przez librecistę transakcentacje. Pisze: „I jeszcze zdarzają się, niestety, pewne polonizmy - w sensie metrycznym, które trzeba będzie zmienić, ale to oczywiście nieważne [...]". Po pierwsze bowiem, takie naruszenia normy językowej utrudniają zrozumienie tekstu (mogą być traktowane jako błędy językowe ${ }^{10}$ ), po drugie - niewykluczone, iż stanowiłyby kłopotliwe zadanie dla kompozytora, który musiałby też ewentualnie deformować rozkład słabych i silnych miejsc taktu, podporządkowując się zapisowi w libretcie.

Publikując tekst Przypowieści, zachowujemy układ graficzny rękopisu, interpunkcję oraz stosowane przez Wata podkreślenia linią ciagłą (lub ich brak), a także błędy i niekonsekwencje.

\title{
Transkrypcja rękopisu ${ }^{11}$
}

\author{
ПРИТЧА О ВОРОБЬЕ, \\ МУЖИКЕ \\ И \\ $\mathrm{BO} \Lambda \mathrm{KE}$
}

СПИКЕР

(баритоном с мрачным равнодушием)

Шел пролеском мужичок

Выпал белый снежечок

Вдруг упал на валенки

Воробьенок маленький
$\underline{\mathrm{XOPH}}$

(то мужской, то женский)

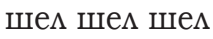

бел бел бел

пал пал пам

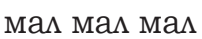

(Пауза)

(В фоне - будто в ярмарочном [przekreślone „суб”] сумбуре (а ^я Стравинский?), мотив „Цыпленок маленький”, и вдруг [przekreślone „слышен издали"] грянул задорный стих:

И воробейчик хочет жить! )

МУжик

(птичьим голосом, местами фистулой, завывая, как горцы в Татрах)

10 Nawiasem mówiąc, Watowi zdarzają się w tym tekście błędy ortograficzne.

11 Tekst utworu Aleksandra Wata publikujemy za zgodą Andrzeja Wata oraz jego syna Pierre'a Wata. Za pomoc w odczytaniu rękopisu dziękujemy pani prof. Ludmile Łucewicz. 

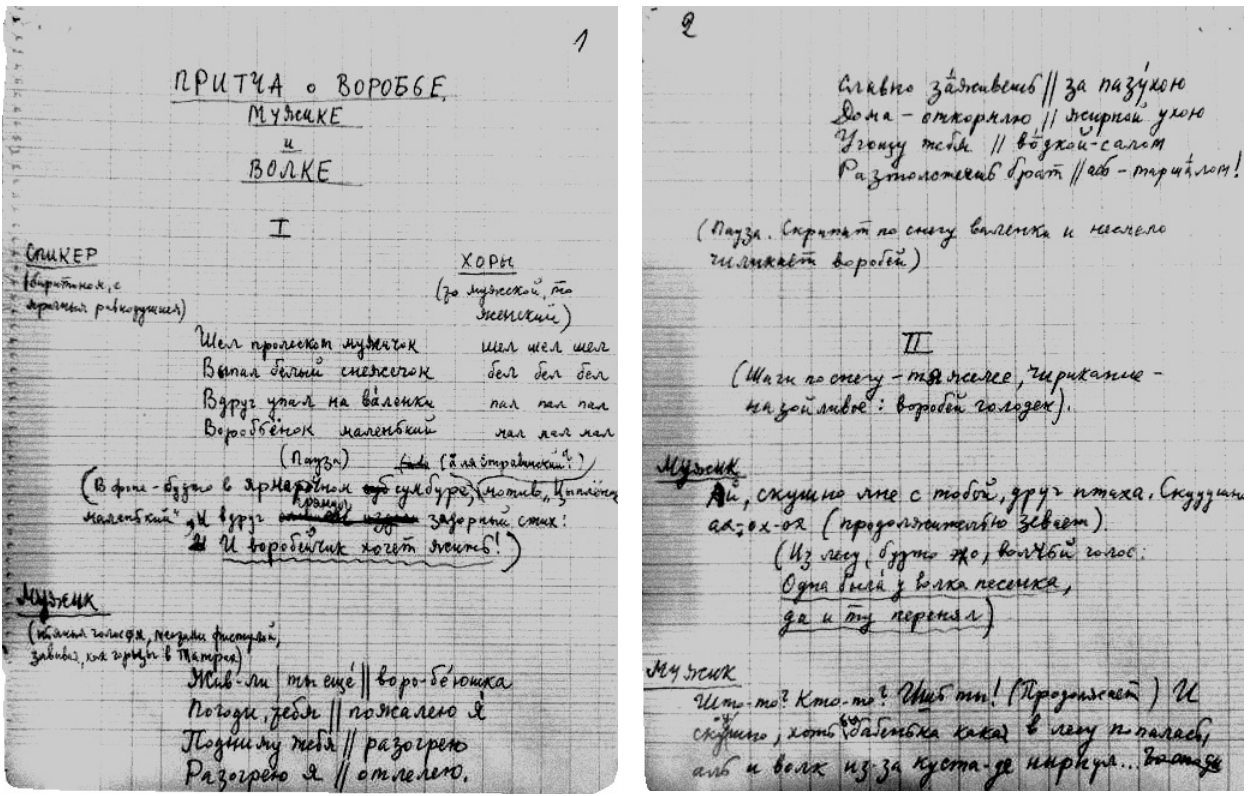

Жив- $и$ / ты еще // воро-беюшка

Погоди, тебя // пожамею я

Подниму тебя // разогрею

Разогрею я // отмемею

Славно за́живешь // за пазухою

Дома - откорммю // жирной ухою

Угощу тебя // во́дкой-салом

Растолстеешь брат // ась - марша́лом!

(Пауза. Скрипят по снегу валенки и несмемо чимикает воробей)

II

(Шаги по снегу - тяжелые, чирикание - назойливое: воробей голоден).

МУЖИК

Ай, скушно мне с тобой, друг птаха. Скууушно, ах-ох-ох (продолжительно зевает).

(Из месу, будто эхо, воцчий голос:

Одна быма у волка песенка,

да и ту переням)

МУЖИК

Што-то? Кто-то? Ишь ты! (Продолжает) И скуушно, хоть бы бабенька какая

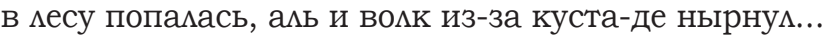

(С испугом) Господи помилуй! Аегок волк на помине. (С внезапным пьяным 
гневом). И доцго мне с тобой возиться? (жалобно) Аишь горе мне с тобой, пташечка-горемыка.

(Вдруг бойко, визгииво)

Я на горке сижу

На красавца гляжу...

(Пауза. Воробей яростно зачирикац. Мужик сипло)

Где тут горка, где красавец,

ишь, тухмырится, мерзавец.

СПИКЕР

(информационно)

Всесто горки и красавца, вместо бабеньки и волка, вижу...

мужик [przekreślone „на напев и”]

(на мотив известной частушки)

- межит.

СПикеР (так же) САышу

МУжик

- смердит...

(скороговоркой) Ну и смердит его! Ай, коровушка, славно, знать, поела! Ай, кормилица, ай гузенница. Да и не видать еe [przekreślone „вовсе”], все мишь бел-снежно. Красота!... Да и где она? И чья она? Ишь, зачикчирикал черт, воробей-разбойник. Чай, почуям. (Шиепнул мадонью по Абу),

Охти-ахти, батюшки святы! (Пауза)
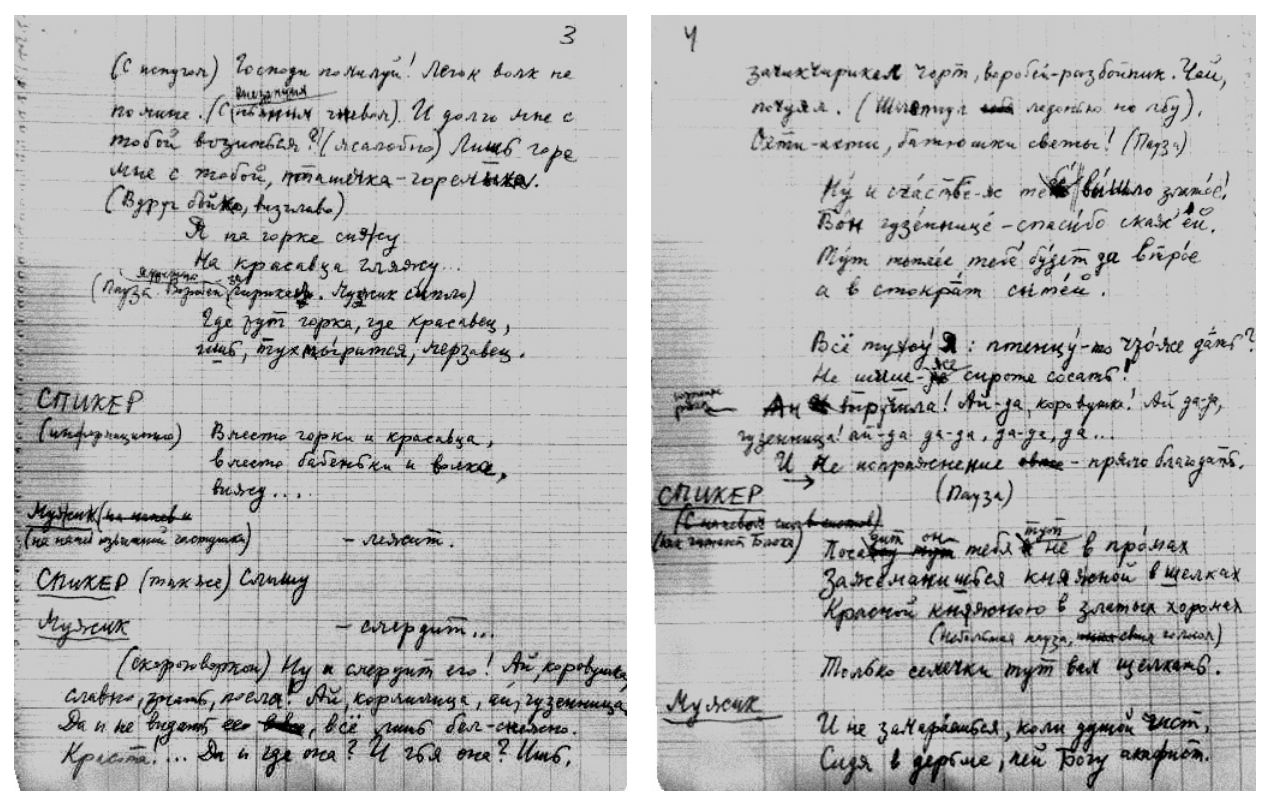
Ну и счастье-же тебе вышио зматое!

Вон гузеннице - спасибо скажи ей.

Тут тепцее тебе будет да втрое,

а в стократ сытей!

Все тужу я: птенцу-то что-же дашь?

Не шиш-же сироте сосать!

Ан выручима! Ай-да, коровушка! Ай да-да,

гузеница! ай-да, да-да, да-да, да...

И не испражнение - прямо благодать.

(Пауза)

\section{СПИКЕР}

[przekreślone „с напевом символистов”]

(как читают Бцока)

Посадит она тебя тут не в промах

Зажеманишься княжной в шелках

Красной княжною в зматых хоромах

(небольшая пауза, своим голосом)

Только семечки тут вам щелкать.

МУЖИК

И не замараешься, коли душой чист,

Сидя в дерьме, пой ${ }^{12}$ Богу акафист.

(Воробей чирикает, хор поет гимн -

[przekreślone „паст”] [następne słowo łacinka] pastorale к [następnie tytuł łacinka] „An der Freude"13[,] который постепено переходит в акафист).

\section{III}

\section{СПИКЕР}

(вдохновенно, как в Радио

декламируют Пушкина)

И вот ушем он, мужиковина-простак[.]

И обернушись взвизгнул: ан-то здравствует!

Поплелся восвояси, след его просты $[$,

а птичья тварь все богу благодарствует.

(Solo воробья)

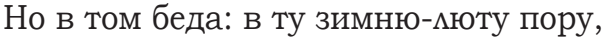

Когда всяк [przekreślone „зверь”] хищник покидает нору,

12 W rękopisie jest „пей” - to ewidentny błąd.

13 Wat popełnił tu drobny błąd w zapisie. Tytuł utworu F. Schillera winien oczywiście brzmieć An die Freude. W zamieszczonych dalej tekstach przekładowych wprowadzono poprawny zapis. 

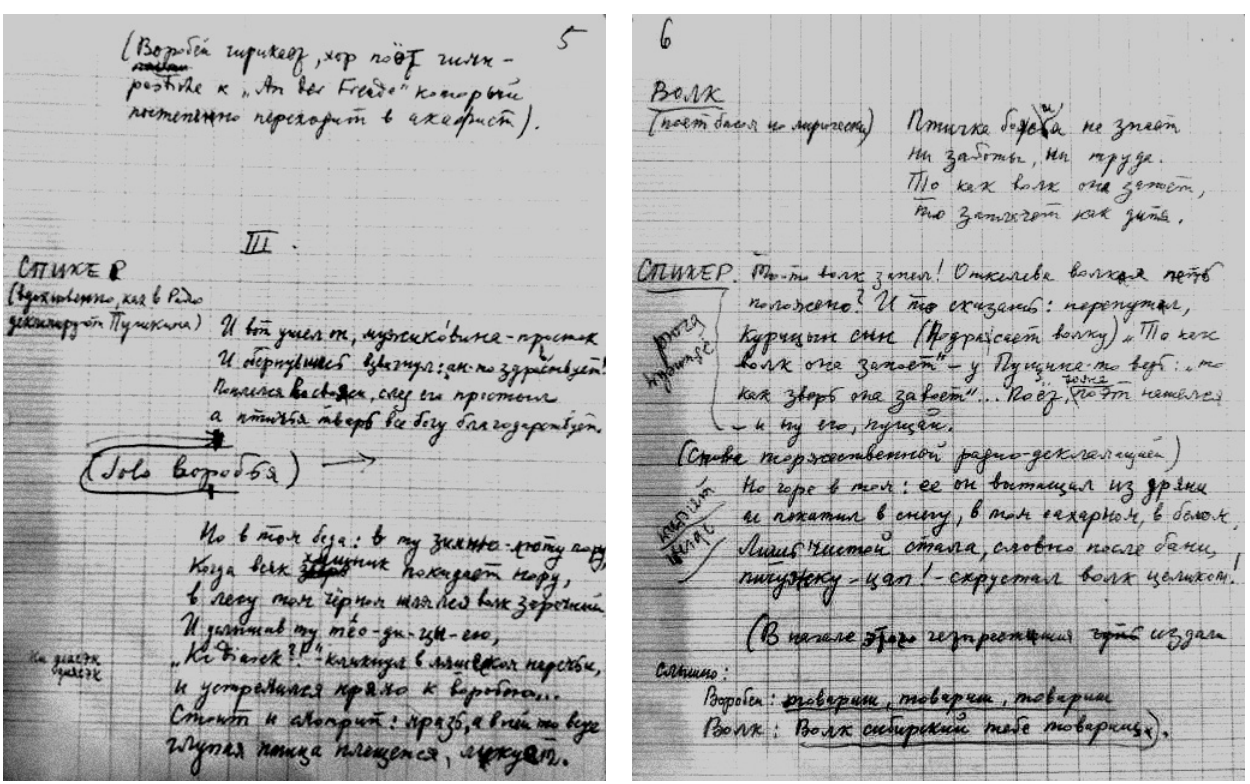

$\underline{\mathrm{BO} \Lambda \mathrm{K}}$

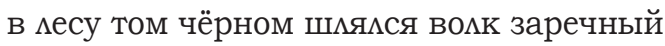

И услышав ту тео-ди-цы-ею,

„Ki diasek?” - кцикнул в $я$ яеском наречьи,

и устремился прямо к воробею...

Стоит и смотрит: мразь, а в ней то всуе

глупая птица плещется, микует.

(поет басом, но Аирически)

Птичка божия не знает ни заботы, ни труда.

То как волк она запоет, то заплачет как дитя ${ }^{14}$.

\section{СПИКЕР}

prozą wysunąc ${ }^{15}$

То-то волк запец! Откелева волкам петь положено? И то скажешь: перепутал, курицын сын (Подражает волку) „То как воцк она запоет” - у Пушкина то ведь: „то как зверь она завоет”... Поёт, тоже поэт нашелся - и ну его, пущай.

(Снова торжественной радио-декламацией)

14 Wat przytacza tu dwa wersy z Wieczoru zimowego A. P u s z k i n a, zamieniając tylko „зверь [zwierz, bestia]” na „волк [wilk]” oraz „завоет [zawyje]” nа „запоет [zaśpiewa]”.

15 Te słowa, a także dalsze: „wierszem wciąć”, Wat zapisał ukośnie po lewej stronie wypowiedzi Narratora. 


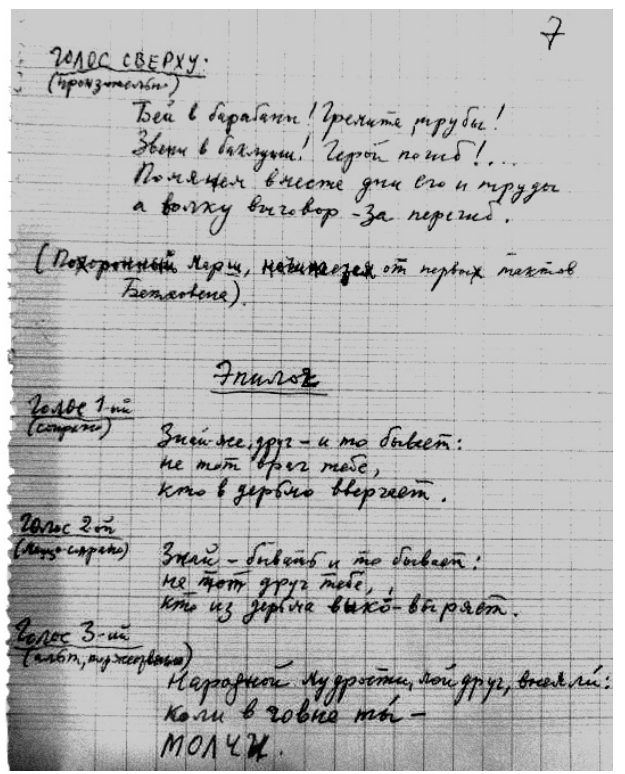

wierszem wciać

Но горе в том: ее он вытащиц из дряни и покатил в снегу, в том сахарном, в белом. Аишь чистой стала, словно после бани, пичужку - цап! - схрустал волк целиком!

(В начале этого четырехстишия [przekreślone „чуть”] издали слышно:

Воробей: товарищ, товарищ, товарищ

Волк: Волк сибирский тебе товариш).

ГО $\Lambda$ OC CBEPXY:

(пронзительно)

Бей в барабаны! Гремите, трубы! Звени в баклуши! Герой погиб!...

Помянем вместе дни его и труды а волку выговор - за перегиб.

(Похоронный марш, начинается от первых тактов Бетховена)

\section{ЭПИАОГ}

Голос 1-ый

(сопрано)

Знай-же, друг - и то бывает:

не тот враг тебе, кто в дерьмо ввергает. 
Голос 2-ой

(меццо-сопрано)

Знай - бывает и то бывает:

не тот друг тебе,

кто из дерьма выко́-выряет.

Голос 3-й

(альт, торжественно)

Народной мудрости, мой друг, внемли:

Коли в говне ты -

МОАЧИ.

Przekład dosłowny

PRZYPOWIEŚĆ O WRÓBLU, CHŁOPIE

i

WILKU

I

NARRATOR

(barytonem - ponuro i obojętnie)

CHÓRY

Szedł chłop zagajnikiem

(raz męski, raz żeński)

Padał biały śnieżek

szedł szedł szedł

biały biały biały

Nagle spadł na walonki

spadł spadł spadł

Wróbelek maleńki

mały mały mały

(Pauza)

(W tle, przebijając się przez gwar targowiska [przekreślone „sub”] (á la Strawiński?), dobiega motyw „Kurczaczek mały”, i nagle [przekreślone „słyszen izdali 〈słyszany z daleka)"] dziarsko huknął śpiew:

Każdy wróbelek pragnie żyć!)

CHŁOP

(ptasim głosem, miejscami falsetem, z zaśpiewem podobnym do tatrzańskich górali)

Żyjesz / jeszcze // wróbeleczku

Poczekaj // ulituję się nad toba

Podniosę cię // ogrzeję

Ogrzeję // wypielęgnuję

Cudnie pożyjesz // za pazuchą

$\mathrm{W}$ domu - odkarmię cię // tłustą uchą 
Ugoszczę cię // wódką-słoniną

Utyjesz bracie // niczym marszałek!

(Pauza. Walonki skrzypią na śniegu i wróbelek zaczyna nieśmiało popiskiwać)

II

(Kroki na śniegu - coraz cięższe, ćwierkanie - coraz bardziej nachalne: wróbelek jest głodny).

CHEOP

Aj, aj, aj, nudno mi z toba, ptaku, przyjacielu. Nuuudno, ach-och-och (ziewa przeciagle).

( $Z$ lasu, niczym echo, donosi się głos wilka: Jedna miał wilk piosenke, A i tę komuś ukradł)

$\underline{\text { CHŁOP }}$

Co to? Kto to? Widzicie go! (Marudzi dalej) Ale nuudy, gdyby tak chociaż jakaś kobitka się w lesie trafiła, albo wilk zza krzaka wyskoczył...

( $Z$ przestrachem) Boże, zmiłuj się! O wilku mowa. (Nagle z pijackim gniewem). Długo mam się tak jeszcze z tobą cackać? (żałośnie) Tylko kłopoty z tobą, ptaszyno nieszczęsna.

(Nagle dziarsko i piskliwie)

Siedzę na pagórku

Patrzę na pięknisia...

(Pauza. Wróbel ćwierka wściekle. Chłop ochryple)

Gdzie tu lasek, gdzie tu piękniś,

Widzisz, marszczy brwi, drań.

NARRATOR

(informacyjnie) Zamiast pagórka i pięknisia, zamiast kobitki i wilka,

widzę...

CHŁoP [przekreślone „na napiew $i\langle$ na melodię i 〉”]

(na melodię znanej czastuszki) - leży.

NARRATOR (tak samo) Czuję

$\underline{\text { CHŁOP }}$

- śmierdzi...

(niewyraźnie i w pośpiechu) No i śmierdzi, jasna jego!... Ej, króweczko, pojadłaś sobie do syta! Ej, żywicielko, ej, kochanieńka! I nic na dodatek nie widać [przekreślone „wowsie 〈w ogóle〉”], tylko śnieżek bialuteńki. Pięknie!... I gdzież to ona? Czyjaż ci ona? Widzicie ją! 
Rozćwierkał się, przeklęty, wróbelek-bandyta. Widać poczuł. (Plasnął się dłonią w czoło). Ech, wy, ojczulkowie święci! (Pauza)

Ależ szczęście ci się trafiło złote!

Ot, żywicielce - jej powiedz dziękuję.

Tu ci będzie cieplej po trzykroć,

a i sto razy więcej sytości!

A ja się tu martwię: co dać pisklakowi?

Przecie nie będzie ssał palucha!

Ależ mi pomogłaś! Aj-ja-aj, karmicielko!

Aj-ja-aj, krówko nasza! Oj, tak-tak, tak-tak, tak-tak...

Toż to nie kupa, tylko błogosławieństwo!

(Pauza)

NARRATOR

[przekreślone „s napiewom simwolistow 〈na melodię symbolistów〉”]

(jak recytuje się Błoka)

Posadzi cię tutaj, ani chybi

Będziesz się krygować niczym księżna w jedwabiach,

Piękna księżna w złotych pałacach

(niewielka pauza, swoim zwyczajnym głosem)

Tylko nasionka sobie tu łuskać.

$\underline{\text { CHŁOP }}$

Nic cię nie splami, jeśli dusza twa czysta,

Siedząc w nawozie, śpiewaj Bogu hymny.

(Wróbel ćwierka, chór śpiewa hymn -

[przekreślone „past” (grażdanka), następne słowo oraz tytuł - łacinkal pastorale $\mathrm{z}$ „An die Freude”[,] które pomału przekształca się w psalm).

III

NARRATOR

( $\mathrm{z}$ uczuciem - jak w radiu

deklamują Puszkina)

I oto odszedł, chłop, prostak[.]

I, odwróciwszy się, aż gwizdnął: takiemu to dobrze!

Poszedł, gdzie go oczy poniosą, ani śladu nie zostawił[,]

a ptasie stworzenie tylko bogu dziękuje.

(Solo wróbla)

Ale cała w tym bieda: w tę zimowa, lodowata porę,

Kiedy każdy [przekreślone „Zwier`〈zwierz〉”] drapieżnik opuszcza norę, w lesie czarnym szwendał się wilk zza rzeki 
I słysząc tę teo-dy-ce-ę,

„Ki diasek?” - zawołał w narzeczu Lachów,

i ruszył prosto do wróbla...

Stoi i patrzy: mierzwa, a w niej na całego

głupi ptak pluszcze się i cieszy.

WILK

(śpiewa basem, ale lirycznie)

Ptaszek boży nie zna

ani kłopotów, ani wysiłku.

To jak wilk zaśpiewa,

to zapłacze jak dziecię.

NARRATOR

prozą wysunąc

Ależ się wilk rozśpiewał! Od kiedy to wilki tak sobie podśpiewują? I jeszcze pokręcił kurzy syn (Naśladuje wilka) „To jak wilk zaśpiewa” - a przecież u Puszkina było „To jak dziki zwierz zawyje”... Wyśpiewuje sobie! Też mi się poeta znalazł a niech go.

(I dalej w tonie uroczystej radiowej deklamacji)

wierszem wciąć

Jedno nieszczęście w tym, że wyciągnął go z gnoju, wytarzał w śniegu jak cukier białym.

Aż czysty stał się, niczym po bani,

i ptaszynkę - haps! - schrupał wilk calutką!

(Od początku tego czterowiersza [przekreślone „czut”] z oddali słychać:

Wróbel: towarzyszu, towarzyszu, towarzyszu

Wilk: Syberyjski wilk ci towarzyszem).

GEOS Z GÓRY:

(przeszywająco)

Bijcie w bębny! Grzmijcie, trąby!

Dzwońcie drewnem! Zginął bohater!...

Wspomnijmy razem dni jego i czyny

a wilkowi nagana - za przegięcie.

(Marsz żałobny, rozpoczyna się od pierwszych taktów Beethovena)

\section{EPILOG}

Głos pierwszy

(sopran)

Wiedz, przyjacielu - i tak się zdarza:

nie ten ci wrogiem,

kto cię w gówno wsadzi. 
Głos drugi

(mezzosopran)

Wiedz - zdarza się i tak się zdarza:

nie ten ci przyjacielem,

kto cię z gnoju wyciagnie.

Głos trzeci

(alt, uroczyście)

Słuchaj, mój przyjacielu, ludowej mądrości:

Gdy siedzisz w gównie -

MILCZ.

Przekład poetycki

PRZYPOWIEŚĆ O WRÓBLU, CHŁOPIE

I

WILKU

I

NARRATOR

(barytonem - ponuro i obojętnie)

CHÓRY

Idzie sobie chłop po lesie

(raz męski, raz żeński)

A wiatr biały śnieżek niesie

lesie lesie lesie

niesie niesie niesie

Nagle spada wprost pod stopy

Mały wróbel temu chłopu

stopy stopy stopy

chłopu chłopu chłopu

(Pauza)

(W tle, przebijając się przez gwar targowiska (á la Strawiński?), dobiega motyw „Kurczaczek mały”, i nagle dziarsko huknął śpiew:

Każdy wróbelek pragnie żyć!)

CHŁOP

(ptasim głosem, miejscami falsetem, z zaśpiewem podobnym do tatrzańskich górali)

Żyjesz / jeszcze // mój maleńki

Czekaj, ja ci // podam rękę

I podniosę cię // przytulę

I ogrzeję // jak matula

Będziesz żył mi // za pazuchą

Zjesz - goracą // tłustą uchę

Dam słoniny // wódki, sera

Będziesz gruby // jak generał!

(Pauza. Walonki skrzypią na śniegu i wróbelek zaczyna nieśmiało popiskiwać) 
II

(Kroki na śniegu coraz cięższe, wróbel ćwierka coraz bardziej nachalnie: jest głodny).

CHEOP

Aj, aj, aj, nudno mi z toba, ptaku, przyjacielu. Nuuudno.

Ach, och, och (ziewa przeciagle).

( $Z$ lasu, niczym echo, donosi się głos wilka:

Jedna miał wilk piosenke,

A i tę komuś ukradł).

CHŁOP

Co ta? Kto to? Widzicie go! (Marudzi dalej) Ale nuudy, gdyby tak chociaż jakaś kobitka się w lesie trafiła, albo wilk zza krzaka wyskoczył...

(Z przestrachem) Boże, zmiłuj się! O wilku mowa. (Nagle z pijackim gniewem). Długo mam się tak jeszcze $\mathrm{z}$ tobą cackać? (żałośnie) Tylko kłopoty z tobą, ptaszyno nieszczęsna.

(Nagle dziarsko i piskliwie)

Siedzę sobie na przylasku

Widzę gościa - cały w blasku...

(Pauza. Wróbel ćwierka wściekle. Chłop ochryple)

Gdzie ten lasek, gdzie ten cwaniak?

Nie ma gościa - kawał drania.

NARRATOR

(informacyjnie) Zamiast lasu i wróbelka, zamiast babki, złego wilka widzę...

CHŁOP

(na melodię znanej czastuszki) - leży.

NARRATOR (tak samo) Czuje

$\underline{\text { CHŁOP }}$

- śmierdzi...

(niewyraźnie i w pośpiechu) No i śmierdzi, jasna jego!... Ej, króweczko, pojadłaś sobie do syta! Ej, żywicielko ty nasza, ej, kochanieńka! I nic na dodatek nie widać, tylko śnieżek bialuteńki. Pięknie!... I gdzież to ona? Czyjaż ci ona? Widzicie ja! Rozświergolił się, przeklęty, wróbelek-bandyta. Widać poczuł. (Plasnął się dłonią w czoło). Ech, wy, ojczulkowie święci! (Pauza)

Ale ci się poszczęściło!

Dziękuj za to krówce miłej.

Tu ci będzie ciepluteńko

I jedzenia stos pod ręką!

A ja się tu martwię: co dać pisklakowi?

Przecie nie będzie ssał palucha! 
Ależ mi pomogłaś! Aj-ja-aj, karmicielko!

Aj-ja-aj, krówko nasza! Oj, tak-tak, tak-tak, tak-tak...

Toż to dzieło sztuki, a nie zwykła kupa!

(Pauza)

NARRATOR

(jak recytuje się Błoka)

Posadzi cię tu na sto procent

I będziesz zgrywał wielką damę,

Księżniczkę, która marszczy nosek

(niewielka pauza, swoim zwyczajnym głosem)

Nic, tylko byś nasionka szamał...

$\underline{\text { CHŁOP }}$

Jeżeli dusza twoja czysta, nic cię nie splami,

Więc siedząc w gównie, wyśpiewuj Bogu psalmy.

(Wróbel ćwierka, chór śpiewa hymn -

pastorale z An die Freude, które pomału przekształca się w psalm).

III

NARRATOR

( $\mathrm{z}$ uczuciem - jak w radiu

deklamują Puszkina)

I oto odszedł, nasz chłop-prostaczek.

Popatrzył tylko: ten to ma pięknie!

Skrył go w zieleni niewielki lasek,

A ptaszek został, śląc Bogu dzięki.

(Solo wróbla)

Nagle nieszczęście: zimową porą,

kiedy drapieżnik opuszcza norę,

gdzieś w lesie czarnym wilk krąży śmiele.

I słyszy taką teo-dy-ce-ę.

„Ki diasek?” - warkną w narzeczu Lachów,

Pędzi, gdzie wróbel ćwierka wśród krzaków...

Stoi i patrzy: łajno, a w kupie

Pławi się wróbel - cieszy się głupek.

WILK

(śpiewa basem, ale lirycznie)

Ptaszek boży nie zna potu,

Ni nieszczęścia, ni kłopotów. 
To jak wilk zaśpiewa w lesie,

To zapłacze niczym dziecię ${ }^{16}$.

\section{NARRATOR}

prozą wysunąć

Ależ się wilk rozśpiewał! Od kiedy to wilki tak sobie podśpiewują? I jeszcze na dodatek pokręcił skurczybyk (Naśladuje wilka) „To jak wilk zaśpiewa w lesie”, a przecież u Puszkina było „To jak dziki zwierz zawyje”... Wyśpiewuje sobie! Też mi się poeta znalazł - a niech go...

(I dalej w tonie uroczystej radiowej deklamacji)

wierszem wciać

I co się stało: wilk go wyjął $\mathrm{z}$ gnoju

wykąpał w śniegu - dużo włożył troski -

aż był czyściutki niczym $z$ wodopoju...

I schrupał ptaszka do ostatniej kostki!

(od początku tego czterowiersza $z$ oddali słychać:

Wróbel: towarzyszu, towarzyszu, towarzyszu

Wilk: Syberyjski wilk ci towarzyszem).

GLOS Z GÓRY:

(przeszywająco)

Bijcie w bębny! Grzmijcie traby!

Sczezł nasz bohater! Niechaj dzwony dźwięczą!

Wspomnijmy jego czyny wiekopomne

A wilka czeka kara za przegięcie.

(Marsz żałobny, rozpoczyna się od pierwszych taktów Beethovena)

\section{EPILOG}

Głos pierwszy

(sopran)

Głos drugi

(mezzosopran)

Wiedz, mój miły - tak się zdarza:

Że nie zawsze ten jest wrogiem,

kto cię w gównie tarza.

I powtarzaj ciagle:

nie zawsze przyjaciel,

kto $\mathrm{z}$ gnoju wyciagnie.

16 W oryginale Wat cytuje wersy 3 i 4 z Wieczoru zimowego A. Pus zkin a. W przekładzie J. Tuw i m a brzmią one tak: „To jak dziki zwierz zawyje, / To jak małe dziecię łka”. 


\title{
Głos trzeci
}

(alt, uroczyście)

Słuchaj, bracie, co lud rzecze:

jeśli siedzisz w gównie,

cicho siedź, człowiecze.

\author{
Abstract \\ ADAM DZIADEK University of Silesia, Katowice \\ ORCID: 0000-0003-4584-5704 \\ PIOTR FAST University of Silesia, Katowice \\ ORCID: 0000-0002-4158-671X
}

\section{ON ALEKSANDER WAT'S UNKNOWN RUSSIAN MANUSCRIPT}

This text is a presentation of a so far unknown work by Aleksander Wat found in the archive of the poet in the Beinecke Rare Book and Manuscript Library at Yale University. It is a part of Alexander Wat Papers with the signature GEN MSS 705 (Box 22 Folder 467). The work was entitled Przypowieśc o wróblu, chłopie i wilku (Parable of a Sparrow, a Peasant and a Wolf) and was written as a libretto to the musical composition of Nicolas Nabokov entitled The Parable of the Sparrow. The Russian version of the song, its transcription, and literal and poetic translations into Polish are included in the paper. Philological and historical literary commentaries complement the presentation. 